\title{
Synthesis, structure, DNA/protein binding, molecular docking and in vitro anticancer activity of two Schiff base coordinated copper(II) complexes
}

\author{
Subal Chandra Manna ${ }^{a, *}$, Soumen Mistri ${ }^{a}$, Apu Patra ${ }^{a}$, Manas Kumar Mahish ${ }^{a}$, Dama Saren ${ }^{a}$, \\ Rajesh Kumar Manne ${ }^{\mathrm{b}}$, Manas Kumar Santra ${ }^{\mathrm{b}}$, Ennio Zangrando ${ }^{\mathrm{c}}$, Horst Puschmann ${ }^{\mathrm{d}}$ \\ a Department of Chemistry and Chemical Technology, Vidyasagar University, Midnapore 721102, West Bengal, India \\ ${ }^{\mathrm{b}}$ National Centre for Cell Science, NCCS Complex, Pune University Campus Ganeshkhind, Pune 411 007, Maharashtra, India \\ ${ }^{\mathrm{c}}$ Department of Chemical and Pharmaceutical Sciences, University of Trieste, 34127 Trieste, Italy \\ ${ }^{\mathrm{d}}$ Department of Chemistry, University of Durham, South Road, Durham DH1 3LE, UK
}

\section{A R T I C L E I N F O}

\section{Article history:}

Received 18 October 2018

Accepted 18 June 2019

Available online 5 July 2019

\section{Keywords:}

Copper(II) complexes

Crystal structure

DNA/protein binding

Molecular docking

Cytotoxicity studies

\begin{abstract}
A B S T R A C $T$
Two Schiff bases HL and $\mathrm{HL}^{\prime}$, having potential tridentate $\mathrm{O}, \mathrm{N}, \mathrm{N}^{\prime}$ donor sets, have been used for the synthesis of two copper(II) complexes, namely $[\mathrm{Cu}(\mathrm{HL})(\mathrm{pdc})]_{2}(\mathbf{1})$ and $\left[\mathrm{Cu}\left(\mathrm{L}^{\prime}\right)_{2}\right]_{2}\left(\mathbf{2}^{\prime}\right)$, where $\mathrm{HL}=2-([2-($ piperazin-yl)ethylimino]methyl)phenol, $\quad \mathrm{pdc}=\mathrm{py}-2,5$-dicarboxylate and $\mathrm{HL}^{\prime}=2-(((2-$-(di-isopropylamino $)$ ethyl)imino)methyl)phenol. X-ray single crystal analysis of complex 1 shows a centro-symmetric dimer. It crystallizes with a number of lattice water molecules that form a network of H-bonds, also involving the protonated piperazinium fragment, giving rise to a 3D supramolecular architecture. Complex $\mathbf{2}^{\prime}$ also crystallizes as dinuclear, formed through mutual bridging phenol oxygen atoms as $\left[\mathrm{Cu}\left(\mathrm{L}^{\prime}\right)_{2}\right]_{2}$, whilst an ESI mass spectrometry study evidences that in solution the complex exists as mononuclear $\left[\mathrm{Cu}\left(\mathrm{L}^{\prime}\right)_{2}\right]$ (2). The interaction of complexes $\mathbf{1}$ and $\mathbf{2}$ with calf thymus DNA (CT-DNA) and with bovine serum albumin (BSA) was investigated using electronic absorption and fluorescence spectroscopic techniques. In both studies the results show a higher binding affinity of complex $\mathbf{1}$ in comparison to $\mathbf{2}$. The anticancer activity of the complexes against human breast (MCF7) cancer cell lines reveals that complex 1 has moderate growth suppression activity against these cells with an $\mathrm{IC}_{50}$ value of $24 \pm 6.24 \mu \mathrm{M}$.
\end{abstract}

(C) 2019 Elsevier Ltd. All rights reserved.

\section{Introduction}

Among the $3 \mathrm{~d}$ metal ions, copper plays an important role in many biological and essential processes, such as electron transfer and oxygen transport, etc. [1]. Recently copper complexes have been widely investigating due to their potential application as metallo-pharmaceuticals [2], and the efficiency of these metal complexes as drugs depends not only on the oxidation states of the metal ions, but also on the ligand framework. The binding affinity of metal complexes with multidentate Schiff base ligands towards DNA and serum albumin is noteworthy in order to access the type of interaction [3]. Moreover, the presence of other coligands along with the Schiff base may affect the copper atom's coordination geometry in the complexes, thus controlling the binding affinity with DNA/proteins [4]. A literature survey reveals that

\footnotetext{
* Corresponding author. Fax: +91 (03222) 275329.

E-mail address: scmanna@mail.vidyasagar.ac.in (S.C. Manna).
}

plenty of copper complexes have been reported with the aim at investigating their interactions with bio molecules (nucleic acids and serum albumins), but relatively few studies involve Schiff base compounds [4].

DNA and proteins are the main molecular targets for drugs and metal complexes, where these compounds exhibit therapeutic effects. Therefore, the study of the interaction of metal complexes with biomolecules is a vital step in the design and synthesis of metal based drugs as anticancer therapeutics. It is well established that transition metal complexes can interact non-covalently with DNA through van der Waals, electrostatic interactions, groove binding and intercalation modes [5]. Among these interactions, intercalation attracts significant attention due to its strong binding mode, opening to possible applications in molecular biology and cancer therapy [6]. In addition, drug-proteins interactions also influence the absorption, metabolism and excretion properties of drugs [7]. Serum albumin acts as drug carrier and plays a very important role in drug delivery processes due to its outstanding 
binding properties. Out of human serum albumin (HSA) and bovine serum albumin (BSA), the second is widely used as a model protein for studying its interactions with molecular species due to its lower cost.

Over the last few years, our group has been involved in the design and synthesis of Schiff base copper(II) coordination compounds. Here we choose a Schiff base bearing a piperazinyl moiety, 2-([2-(piperazin-yl)ethylimino]methyl)phenol (HL), and an ethylene diamine based one, 2-(((2-(di-isopropylamino)ethyl)imino) methyl)phenol $\left(\mathrm{HL}^{\prime}\right)$, for the synthesis of $[\mathrm{Cu}(\mathrm{HL})(2,5-\mathrm{pdc})]_{2}(\mathbf{1})$ and $\left[\mathrm{Cu}\left(\mathrm{L}^{\prime}\right)_{2}\right]_{2}\left(\mathbf{2}^{\prime}\right)$, respectively. The interaction of these complexes with CT-DNA and BSA was studied using spectroscopic techniques. We have also tested the cytotoxicity of the complexes against MCF7 cancer cell lines. The molecular docking technique has been used to access the mode of interaction of these complexes with DNA/protein.

\section{Experimental}

\subsection{Materials}

High purity 2-ethylaminopiperazine and N,N-diisopropyl ethylene diamine were purchased from the Aldrich Chemical Co. Inc. and used as received. All other chemicals used were of analytical grade. Solvents used for spectroscopic studies were purified and dried by standard procedures before use [8].

\subsection{Physical measurements}

Elemental analyses (carbon, hydrogen and nitrogen) were performed using a Perkin-Elmer 240C elemental analyzer. IR spectra were recorded as $\mathrm{KBr}$ pellets on a Bruker Vector 22FT IR spectrophotometer operating from 400 to $4000 \mathrm{~cm}^{-1}$. NMR spectra of the ligand were recorded on a Bruker $400 \mathrm{MHz}$ instrument. The ESI-MS spectrum of compound $\mathbf{1}$ (in dichloromethane) was recorded on a LC-MS/MS system, Q-Tof Premier mass spectrometer. The ESI-MS spectrum of compound $\mathbf{2}^{\prime}$ (in acetonitrile) was recorded with a Waters QtoF Model YA 263 mass spectrometer. Electronic absorption spectra were obtained with a Shimadzu UV-1601 UV-Vis spectrophotometer at room temperature. Quartz cuvettes with a $1 \mathrm{~cm}$ pathlength and a $3 \mathrm{~cm}^{3}$ volume were used for all measurements. Emission spectra were recorded on a Hitachi F7000 spectrofluorimeter. Room temperature (300 K) spectra were obtained in dichloromethane solution using a quartz cell of $1 \mathrm{~cm}$ path length. The slit width was $2.5 \mathrm{~nm}$ for both excitation and emission.

\subsection{Synthesis of the ligands}

The ligands 2-([2-(pyperazin-1-yl)ethylimino]methyl)phenol (HL) and 2-(((2-(di-isopropylamino)ethyl)imino)methyl)phenol $\left(\mathrm{HL}^{\prime}\right)$ were prepared by the condensation reaction of salicylaldehyde and the related amines in a 1:1 ratio in methanol for $3 \mathrm{~h}$. Details of the synthesis and characterization of the ligands are given in a Supplementary file. ${ }^{1} \mathrm{H}$ and ${ }^{13} \mathrm{C}$ NMR spectra of $\mathrm{HL}$ and $\mathrm{HL}^{\prime}$ in $\mathrm{CDCl}_{3}$ are shown in Figs. $1 \mathrm{~S}-4 \mathrm{~S}$.

\subsection{Synthesis of the complexes}

Caution! The perchlorate salts were used in small quantities and handled with care since explosions may occur.

\subsubsection{Synthesis of $[\mathrm{Cu}(\mathrm{HL})(2,5-\mathrm{pdc})]_{2}(\mathbf{1})$}

The ligand HL ( $1 \mathrm{mmol}, 0.23 \mathrm{~g})$ in methanol was deprotonated with triethylamine and added into a methanolic solution of
$\mathrm{Cu}\left(\mathrm{ClO}_{4}\right)_{2} \cdot 6 \mathrm{H}_{2} \mathrm{O}(1 \mathrm{mmol}, 0.37 \mathrm{~g})$, stirring the mixture for $2 \mathrm{~h}$. A methanol-water solution of disodium pyridine-2,5-dicarboxylate ( $\mathrm{Na}_{2} \mathrm{pdc}$ ) ( $1 \mathrm{mmol}, 0.21 \mathrm{~g}$ ) was slowly added to the resulting deep green solution and stirred for an additional $1 \mathrm{~h}$. The resulting filtrate was kept in air. Deep green needle shaped single crystals suitable for X-ray diffraction were obtained by slow evaporation of methanol solution after two days. Yield: $0.720 \mathrm{~g}$ (75\%). Anal. Calc. For $\mathrm{C}_{40} \mathrm{H}_{44} \mathrm{Cu}_{2} \mathrm{~N}_{8} \mathrm{O}_{10} \cdot 12 \mathrm{H}_{2} \mathrm{O}$ (1140.10): C, 42.14; $\mathrm{H}, 6.01 ; \mathrm{N}, 9.83 \%$ Found: C, 42.01; H, 6.03; N, $9.75 \%$. IR $\left(\mathrm{cm}^{-1}\right)$ : 3800-3000 (br,s), 2975(s), 2943(w), 1652(w), 1561(s), 1467(s), 1419(s), 1370(s), 1251(vw), 1124(vw), 1079(s), 1008(w), 885(s), 817(s), 652(w), 509(w).

\subsubsection{Synthesis of $\left[\mathrm{Cu}\left(\mathrm{L}^{\prime}\right)_{2}\right]_{2}\left(\mathbf{2}^{\prime}\right)$}

The ligand HL' (2 mmol, $0.49 \mathrm{~g}$ ) in methanol (10 mL) was deprotonated with triethylamine and added dropwise into a methanolic solution $(10 \mathrm{~mL})$ of $\mathrm{Cu}\left(\mathrm{ClO}_{4}\right)_{2} \cdot 6 \mathrm{H}_{2} \mathrm{O}(1 \mathrm{mmol}, 0.37 \mathrm{~g})$ under stirring. A methanol-water solution of disodium pyridine-2,5-dicarboxylate $\left(\mathrm{Na}_{2} \mathrm{pdc}\right)$ ( $1 \mathrm{mmol}, 0.21 \mathrm{~g}$ ) was slowly added to the resulting deep green solution and stirred for additional $2 \mathrm{~h}$, then filtered. The green color filtrate was kept in air for slow evaporation and single crystals suitable for X-ray diffraction were obtained after a few days. Yield: $0.468 \mathrm{~g}$ (84 \%). Anal. Calc. For $\mathrm{C}_{60} \mathrm{H}_{92} \mathrm{Cu}_{2} \mathrm{~N}_{8} \mathrm{O}_{4}$ (1116.49): C, 64.48; H, 8.23; N, 10.03 \%. Found: C, 64.45; H, 8.26; N, 10.06 \%. IR (cm $\left.{ }^{-1}\right):$ 2960(w), 2907(w), 1628(s), 1540(s), 1443 (w), 1243(vw), 1396(vw), 1208(w), 1064(w), 754(s), 568(w).

\subsection{Crystallographic data collection and refinement}

Data collection for complexes $\mathbf{1}$ and $\mathbf{2}^{\prime}$ was carried out with Mo $\mathrm{K} \alpha$ radiation $(\lambda=0.71073 \AA)$ on an Xcalibur, Sapphire 3 and on a Bruker APEX-II CCD diffractometer, respectively. Experiments were performed at 120(2) K and at ambient temperature, for $\mathbf{1}$ and $\mathbf{2}^{\prime}$, respectively. Cell refinement, indexing and scaling of the data sets were done by using the CrysAlis PRO package [9] and BrukerAPEX2 and SAINT programs [10]. Both the structures were solved by direct methods and subsequent Fourier analyses $[11,12]$ and refined by the full-matrix least-squares method based on $F^{2}$ with all observed reflections [12]. In compound $\mathbf{1}$, one of water lattice molecules was found to be disordered over two positions and occupancies were refined to $0.54(6) / 0.46(6)$. Hydrogen atoms were placed at calculated positions, except those of the water molecules, detected on the difference Fourier map and refined with restrained $\mathrm{O}-\mathrm{H}$ distances of 0.85 A. Publication material was prepared with the Olex2 program [13] and WinGX package [14]. Crystal data and details of the refinements are given in Table 1.

\subsection{CT-DNA binding experiments}

Electronic absorption spectral titrations were carried out at a fixed concentration of the complexes ( $3 \mathrm{~mL}, 0.068 \mathrm{mM}$ ) in dichloromethane and with varying concentrations of CT-DNA. The intrinsic binding constant $\left(K_{\mathrm{ib}}\right)$ of the complexes with CT-DNA was determined using the equation [15]:

$$
\frac{[\mathrm{DNA}]}{\left(\varepsilon_{\mathrm{f}}-\varepsilon_{\mathrm{a}}\right)}=\frac{[\mathrm{DNA}]}{\left(\varepsilon_{\mathrm{f}}-\varepsilon_{\mathrm{b}}\right)}+\frac{1}{K_{\mathrm{ib}}\left(\varepsilon_{\mathrm{f}}-\varepsilon_{\mathrm{b}}\right)}
$$

where [DNA] is the concentration of CT-DNA, $\varepsilon_{\mathrm{a}}$ is the extinction coefficient of the complex at a given CT-DNA concentration, $\varepsilon_{\mathrm{f}}$ and $\varepsilon_{\mathrm{b}}$ are the extinction coefficients of the complex in solution and when fully bound to CT-DNA, respectively. A plot of [DNA]/( $\left.\varepsilon_{\mathrm{f}}-\varepsilon_{\mathrm{a}}\right)$ versus [DNA] gives a straight line with $1 /\left(\varepsilon_{\mathrm{f}}-\varepsilon_{\mathrm{b}}\right)$ and $1 /\left[K_{\mathrm{ib}}\left(\varepsilon_{\mathrm{f}}-\varepsilon_{\mathrm{b}}\right)\right]$ as the slope and intercept, respectively. The value of $\mathrm{K}_{\mathrm{ib}}$ was calculated from the ratio of the slope to the intercept. 
Table 1

Crystal data and details of structure refinement for complexes $\mathbf{1}$ and $\mathbf{2}^{\prime}$.

\begin{tabular}{|c|c|c|}
\hline Complex & $\mathbf{1} \cdot 12 \mathrm{H}_{2} \mathrm{O}$ & $\mathbf{2}^{\prime}$ \\
\hline Empirical formula & $\mathrm{C}_{40} \mathrm{H}_{68} \mathrm{Cu}_{2} \mathrm{~N}_{8} \mathrm{O}_{22}$ & $\mathrm{C}_{60} \mathrm{H}_{92} \mathrm{Cu}_{2} \mathrm{~N}_{8} \mathrm{O}_{4}$ \\
\hline Formula mass, $\mathrm{g} \mathrm{mol}^{-1}$ & 1140.10 & 1116.49 \\
\hline Crystal system & triclinic & monoclinic \\
\hline Space group & $P \overline{1}$ & $P 2_{1} / \mathrm{n}$ \\
\hline$a(\AA)$ & $7.7383(6)$ & $16.054(6)$ \\
\hline$b(\AA)$ & $11.5130(12)$ & $9.283(3)$ \\
\hline$c(\AA)$ & $14.7643(16)$ & $20.130(8)$ \\
\hline$\alpha\left({ }^{\circ}\right)$ & $76.790(9)$ & 90.0 \\
\hline$\beta\left(^{\circ}\right)$ & $75.401(8)$ & $94.52(3)$ \\
\hline$\gamma\left({ }^{\circ}\right)$ & $79.109(8)$ & 90.0 \\
\hline$V(\AA)^{3}$ & $1227.1(2)$ & 2991(2) \\
\hline$Z$ & 1 & 2 \\
\hline$D_{(\text {calcd })}, \mathrm{g} \mathrm{cm}^{-3}$ & 1.543 & 1.240 \\
\hline$\mu($ Mo K $\alpha), \mathrm{mm}^{-1}$ & 0.956 & 0.762 \\
\hline$F\left(\begin{array}{lllllllllll}0 & 0 & 0\end{array}\right)$ & 598 & 1196 \\
\hline Theta range $\left(^{\circ}\right)$ & $2.11-25.35$ & $2.4172-23.56$ \\
\hline No. of collected data & 12821 & 62658 \\
\hline No. of unique data & 4265 & 4439 \\
\hline$R_{\text {int }}$ & 0.1226 & 0.0597 \\
\hline Obs reflects $[I>2 \sigma(I)]$ & 2891 & 3769 \\
\hline Goodness of fit $\left(F^{2}\right)$ & 1.045 & 1.043 \\
\hline Parameters refined & 371 & 342 \\
\hline$R 1, w R 2(I>2 \sigma(I))^{\mathrm{a}}$ & $0.0928,0.2129$ & $0.0387,0.0983$ \\
\hline$R 1, w R 2$ (all data) & $0.1388,0.2407$ & $0.0481,0.1056$ \\
\hline Residuals, e $\AA^{-3}$ & $1.094,-0.823$ & $0.789,-0.371$ \\
\hline
\end{tabular}

${ }^{a} R 1(F o)=\Sigma|| F o|-| F c|| / \Sigma|F o|, w R 2\left(F 0^{2}\right)=\left[\Sigma w\left(F 0^{2}-F c^{2}\right)^{2} / \Sigma w\left(F o^{2}\right)^{2}\right]^{1 / 2}$.

\subsection{BSA binding studies}

A stock solution of bovine serum albumin (BSA) was prepared in $55 \mathrm{mM}$ HEPES buffer ( $\mathrm{pH}$ 7.2). The solutions of the copper complexes were prepared by dissolving the compounds in water: HEPES buffer (1:99) mixture. The interaction of the compounds with serum albumin was studied by recording the tryptophan fluorescence of BSA. Complexes $\mathbf{1}$ and $\mathbf{2}$ were added at room temperature to the BSA solution $(3.263 \mu \mathrm{M})$ and the quenching of the emission intensities at $340 \mathrm{~nm}\left(\lambda_{\mathrm{ex}}, 280 \mathrm{~nm}\right)$ was recorded with gradual addition of a dichloromethane solution $(0.068 \mathrm{Mm})$ of the complexes.

\subsection{Cell culture}

The breast cancer cell line MCF7 was cultured in DMEM medium as monolayers supplemented with $10 \%$ FBS, $100 \mathrm{U} / \mathrm{ml}$ penicillin and $100 \mu \mathrm{g} / \mathrm{ml}$ streptomycin at $37^{\circ} \mathrm{C}$ in a humid atmosphere of $5 \% \mathrm{CO}_{2}$.

\subsection{In vitro cytotoxicity assay}

The cytotoxicity of complexes $\mathbf{1}$ and $\mathbf{2}$ was determined by an MTT (3-(4,5-dimethylthiazol-2-yl)-2-5 diphenyltetrazolium bromide) assay. MCF7 cells were seeded in 96-well plates at $5 \times 10^{3}$ cells per well. Cells were treated with different concentrations $(0.01-100 \mu \mathrm{M})$ in triplicate for $48 \mathrm{~h}$. The MTT solution was then added to each well and further incubated for $3.5 \mathrm{~h}$ at $37^{\circ} \mathrm{C}$ in a humid atmosphere, $5 \% \mathrm{CO}_{2}$. Finally, the MTT containing media was discarded and solvent (iso-propanol, $\mathrm{HCl}$ and Triton $\mathrm{X}-100$ ) was added to each well and incubated for $15 \mathrm{~min}$ at room temperature with gentle rocking. The absorbance was read in a Thermo Pierce Elisa plate reader at $570 \mathrm{~nm}$, and the results were expressed as the percentage inhibition relative to the cells treated with DMSO (considered as 0\%). Each experiment was repeated three times.

\subsection{Molecular docking}

\subsubsection{DNA-complex docking}

We used the HEX 6.3 program to study the DNA-complex interaction and Spherical Polar Fourier Correlations to perform docking. The B-DNA dodecamer d(CGCGAATTCGCG) 2 (PDB ID: 1bna) (http:// www.rcsb.org./pdb) was used as a model compound for CT-DNA [16a]. The molecular structures of $\mathbf{1}$ and $\mathbf{2}$ were optimized using Gaussian 09 [16b]. The geometries of the complexes under study were optimized using standard 6-31G basis sets for $\mathrm{N}, \mathrm{C}, \mathrm{H}$ and $\mathrm{O}$ atoms and LANL2DZ for the $\mathrm{Cu}$ atom. The binding energy of the complexes with DNA was minimized using the semi-empirical AM1 method of the Chimera program. The following parameters were used for docking: correlation type - shape only, FFT mode $3 \mathrm{D}$, grid dimension -0.6 , receptor range -180 , ligand range 180 , twist range -360 , distance range -40 . PyMol software was used for visualization of the docked pose.

\subsubsection{BSA-complex docking}

The AutoDock4.2 [17] software was used to perform BSA-complex docking. The structure of BSA (PDB ID: 4f5s), downloaded from the Protein Data Bank (http://www.rcsb.org/pdb), was used for docking and the Chimera program (http://www.cgl.ucsf.edu/ chimera/) was used for receptor preparation. The molecular structures of $\mathbf{1}$ and $\mathbf{2}$ were optimized by using Gaussian 09 [16b]. The geometries of the complexes under study were optimized using standard 6-31G basis sets for the N, C, H and $\mathrm{O}$ atoms and LANL2DZ for the $\mathrm{Cu}$ atom. In order to recognize the binding sites in BSA, the grid size was set to 100,100 and 100 along the $X$-, $Y$ - and $Z$-axes, with a $0.375 \AA$ grid spacing. The docking results were visualized by Chimera (http://www.cgl.ucsf.edu/chimera/) and PyMol software.

\section{Results and discussion}

\subsection{Synthetic aspects}

The multisite coordinating ligands $\mathrm{HL}$ and $\mathrm{HL}^{\prime}$ were prepared by the condensation reaction of the corresponding amine and aldehyde in methanol under reflux conditions, and characterized by NMR (Figs. 1S-4S) and FT-IR (Figs. 5S and 6S). Using HL and HL', complexes $\mathbf{1}$ and $\mathbf{2}^{\prime}$ were synthesized by adopting the procedures as schematically displayed in Scheme 1.

\subsection{Crystal structure description}

\subsection{1. $[\mathrm{Cu}(\mathrm{HL})(2,5-\mathrm{pdc})]_{2}(\mathbf{1})$}

The X-ray structural analysis of complex $\mathbf{1}$ evidences a $\mu$-phenoxo bridged dimer, affording a planar $\mathrm{Cu}_{2} \mathrm{O}_{2}$ moiety arranged about a crystallographic inversion center, crystallizing with twelve lattice water molecules. The molecular structure of the complex is shown in Fig. 1 and selected bond lengths and angles are listed in Table 2 . Each symmetry related copper center exhibits a coordination environment best described by an approximately square-pyramidal geometry, with the basal plane sites occupied by the chelating Schiff base ligand through the phenol oxygen and the imino nitrogen atoms, and by the pyridine dicarboxylate anion. The coordination is completed by the phenoxo oxygen atom of the symmetry related complex unit at the apical position. Here the propensity of the pyridine dicarboxylate anion to act as a chelating ligand induces the Schiff base to behave as bidentate and the piperazine nitrogen atoms do not participate in coordination, the ethyl-piperazinium fragment being oriented far away from the metal center, although in some structurally characterized examples this ligand acts as an $\mathrm{O}, \mathrm{N}, \mathrm{N}$-tridentate chelating species, 


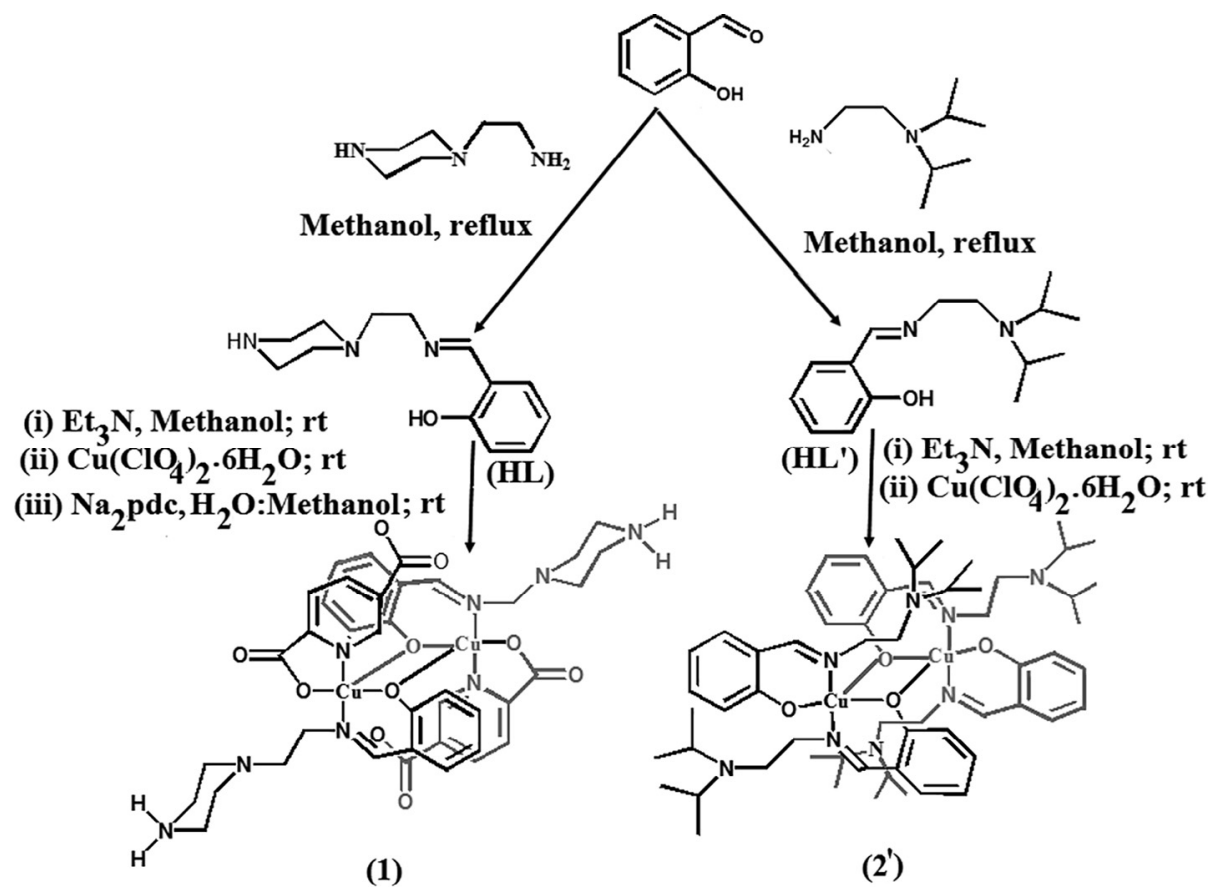

Scheme 1. Synthesis of complexes 1 and $\mathbf{2}^{\prime}$.

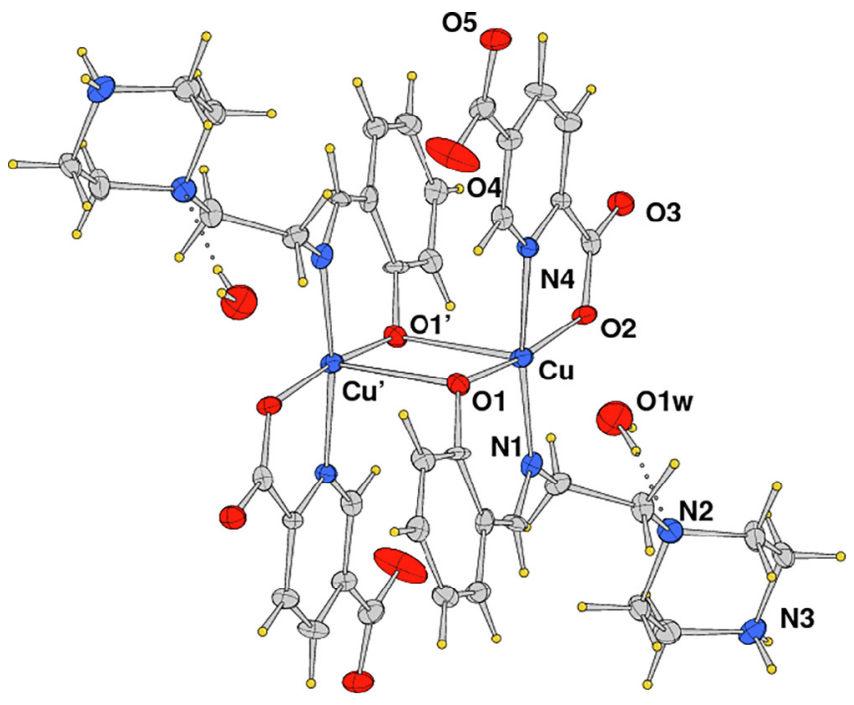

Fig. 1. ORTEP drawing (thermal ellipsoids at $40 \%$ probability) of dimeric species of 1 (primed atoms at $1-x, 1-y,-z$ )

also involving the piperazine nitrogen atom [18]. The two $\mathrm{Cu}-\mathrm{O}$ as well as $\mathrm{Cu}-\mathrm{N}$ bond distances are slightly different, being $1.897(5)$, 1.968(5) and 1.959(7), 2.016(6) $\AA$, respectively The apical $\mathrm{Cu}-\mathrm{O}(1)$ bond in the square-pyramidal environment is the longest, as expected, with a length of 2.503(6) A. The bond angles do not deviate significantly from those of a regular geometry and the $\mathrm{O}(2)-\mathrm{Cu}-\mathrm{N}(4)$ angle, of $81.6(2)^{\circ}$, has the largest deviation from the ideal value. The $\mathrm{Cu}_{2} \mathrm{O}_{2}$ core of the complex dimer is close to a square, with a $\mathrm{Cu}-\mathrm{O}(1)-\mathrm{Cu}^{\prime}$ bond angle of $96.7(2)^{\circ}$ that gives a metal-metal separation of $3.312 \AA$. It is worth noting that the nitrogen atom at position 4 of the piperazine ring is protonated, so that the ligand is neutral in its zwitter ionic form. This protonated nitrogen atom $\mathrm{N}(3)$ is involved in rather strong $\mathrm{H}$-bonds with a water molecule and a carboxylate oxygen atom ( $\mathrm{NH}$...Ow of 2.757(9) and 2.749(10) $\AA$ ), and $\mathrm{N}(2)$ acts as an acceptor with
Table 2

Coordination bond distances $(\AA)$ and angles $\left(^{\circ}\right)$ for complexes $\mathbf{1}$ and $\mathbf{2}^{\prime}$.

\begin{tabular}{lll}
\hline & $\mathbf{1}$ & $\mathbf{2}^{\prime}$ \\
\hline $\mathrm{Cu}-\mathrm{O}(1)$ & $1.897(5)$ & $1.9214(18)$ \\
$\mathrm{Cu}-\mathrm{O}(2)$ & $1.968(5)$ & $1.8861(19)$ \\
$\mathrm{Cu}-\mathrm{N}(1)$ & $1.959(7)$ & $2.019(2)$ \\
$\mathrm{Cu}-\mathrm{N}(4)$ & $2.017(6)$ & $2.000(2)$ \\
$\mathrm{Cu}-\mathrm{O}\left(1^{\prime}\right)$ & $2.503(6)$ & $2.3120(19)$ \\
$\mathrm{O}(1)-\mathrm{Cu}-\mathrm{O}(2)$ & $172.0(2)$ & $169.14(8)$ \\
$\mathrm{O}(1)-\mathrm{Cu}-\mathrm{N}(1)$ & $93.7(2)$ & $89.80(8)$ \\
$\mathrm{O}(1)-\mathrm{Cu}-\mathrm{N}(4)$ & $90.7(2)$ & $93.80(9)$ \\
$\mathrm{O}(2)-\mathrm{Cu}-\mathrm{N}(4)$ & $81.5(2)$ & $92.44(9)$ \\
$\mathrm{N}(1)-\mathrm{Cu}-\mathrm{O}(2)$ & $94.2(2)$ & $91.29(9)$ \\
$\mathrm{N}(1)-\mathrm{Cu}-\mathrm{N}(4)$ & $172.0(2)$ & $139.12(9)$ \\
$\mathrm{O}(1)-\mathrm{Cu}-\mathrm{O}\left(1^{\prime}\right)$ & $83.3(2)$ & $75.27(8)$ \\
$\mathrm{O}(2)-\mathrm{Cu}-\mathrm{O}\left(1^{\prime}\right)$ & $95.2(2)$ & $94.53(8)$ \\
$\mathrm{N}(1)-\mathrm{Cu}-\mathrm{O}\left(1^{\prime}\right)$ & $94.3(2)$ & $115.21(8)$ \\
$\mathrm{N}(4)-\mathrm{Cu}-\mathrm{O}\left(1^{\prime}\right)$ & $92.9(2)$ & $105.04(8)$ \\
$\mathrm{Cu}-\mathrm{O}(1)-\mathrm{Cu}$ & $96.7(2)$ & $104.73(8)$ \\
$\mathrm{O}(1)-\mathrm{Cu}-\mathrm{O}\left(1^{\prime}\right)$ & $83.3(2)$ & $75.28(7)$
\end{tabular}

Primed atoms at $1-x, 1-y,-z$ for $\mathbf{1}$, and at $1-x, 1-y, 1-z$ for $\mathbf{2}^{\prime}$.

respect to the water molecule $\mathrm{O}(1 \mathrm{w})(\mathrm{N}(2) \ldots \mathrm{O}(1 \mathrm{w})$ of $2.832(9)$ $\AA$ A). The crystal packing shows a 3D structure for a network of $\mathrm{H}$ bonds to the numerous lattice water molecules (Fig. 2), the geometries of which are reported in Table 1S.

\subsection{2. $\left[\mathrm{Cu}\left(\mathrm{L}^{\prime}\right)_{2}\right]_{2}\left(\mathbf{2}^{\prime}\right)$}

The structural analysis of $\left[\mathrm{Cu}\left(\mathrm{L}^{\prime}\right)_{2}\right]_{2}\left(\mathbf{2}^{\prime}\right)$ reveals in solid state discrete centro-symmetric dimer species where the copper atom is bis-chelated by the deprotonated Shiff base ligands through the phenol oxygen and the imino nitrogen donors, but the phenol oxygen atoms of one chelating ligand and of its symmetry counterpart

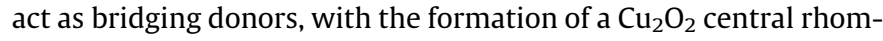
boid moiety. The metal environment can be best described as distorted square pyramidal. A selection of bond lengths and angles of this complex is reported in Table 2 and an Ortep drawing is shown in Fig. 3. The $\mathrm{Cu}-\mathrm{O}$ bond lengths in the basal plane are 1.8861(19) and $1.9214(18) \AA$ (the latter value refers to the bridging oxygen 


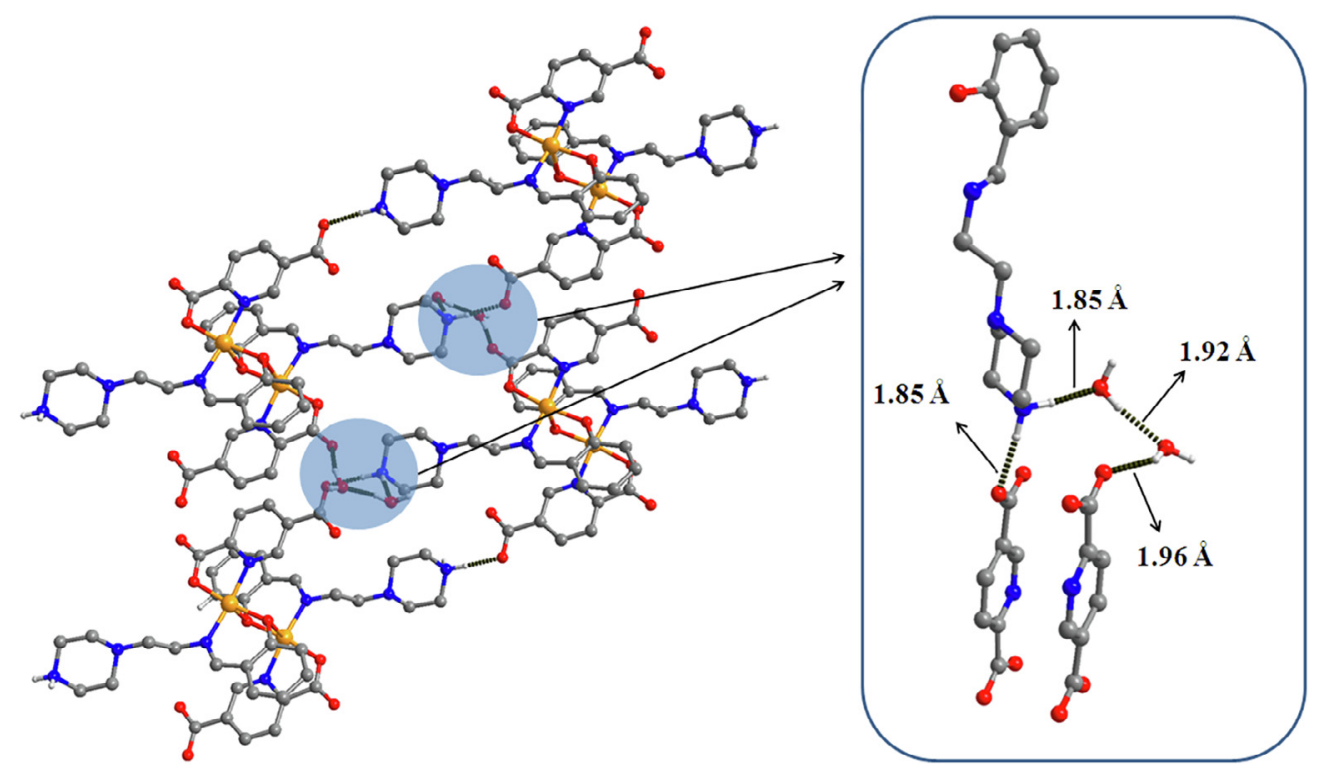

Fig. 2. 3D structure of $\mathbf{1}$ through hydrogen bonding interactions.

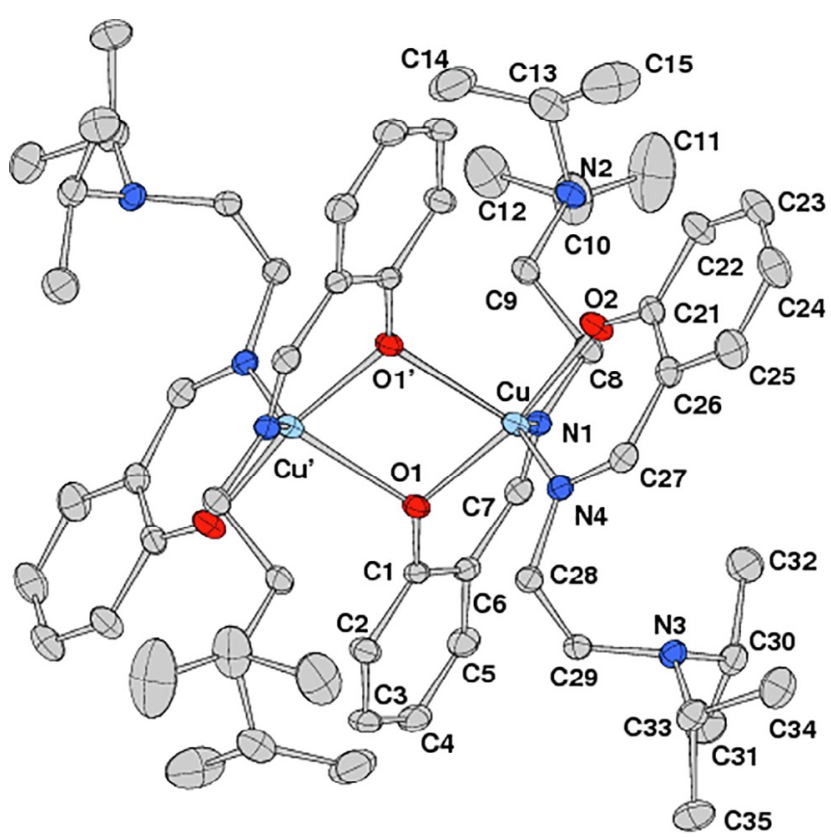

Fig. 3. ORTEP drawing of $\mathbf{2}^{\prime}$ (thermal ellipsoids at $20 \%$ probability, $\mathrm{H}$ atoms omitted for clarity) with the atomic labels for the crystallographic independent unit. Primed atoms at $1-x, 1-y, 1-z$.

atom 01 ), and the $\mathrm{Cu}-\mathrm{N}$ ones are of 2.019(2) and 2.000(2) $\AA$, in agreement with those measured in $\mathbf{1}$. The oxygen atom at the apical position is at $2.3120(19) \AA$. The $\mathrm{Cu}_{2} \mathrm{O}_{2}$ rhomboid unit is slightly different from that of $\mathbf{1}$ with a $\mathrm{Cu}-\mathrm{O}(1)-\mathrm{Cu}^{\prime}$ angle of $104.73(8)^{\circ}$ and with the metal atoms separated by $3.361 \AA$. Due to the steric hindrance of the di-isopropyl amino groups, but also to accomplish the short apical bond distance for $\mathrm{Cu}-\mathrm{O}^{\prime}{ }^{\prime}(2.3120(19) \AA)$, the coordination square of the copper atom is significantly distorted towards a tetrahedral configuration, having $\mathrm{O}-\mathrm{Cu}-\mathrm{O}$ and $\mathrm{N}-\mathrm{Cu}-\mathrm{N}$ coordination bond angles of $169.14(8)$ and $139.12(9)^{\circ}$, the latter considerably deviating from the ideal value of $180^{\circ}$.

The reported observations indicate the tendency of these complexes to form $\mu$-phenoxo bridged dimers and, in addition to complex 1, different examples have been reported elsewhere $[19,20]$.

\subsection{IR and electronic spectra}

IR spectra of HL, HL' and of complexes $\mathbf{1}$ and $\mathbf{2}^{\prime}$ are shown in Figs. 5S, 6S, 7S and 8S, respectively, and the most important IR bands with their tentative assignments are given in Table $2 \mathrm{~S}$. The IR spectrum of complex 1 exhibits a broad band in the region $3800-3000 \mathrm{~cm}^{-1}$, assigned to the $v(\mathrm{O}-\mathrm{H})$ stretching vibrations of water molecules [21a]. Bands at 2982, 2992, 2975 and $2985 \mathrm{~cm}^{-1}$ for $\mathrm{HL}, \mathrm{HL}^{\prime}, \mathbf{1}$ and $\mathbf{2}^{\prime}$, respectively, correspond to $v\left(\mathrm{C}_{\mathrm{sp}}^{2}-\mathrm{H}\right)$ stretching frequencies and those at 2918, 2920, 2943 and $2960 \mathrm{~cm}^{-1}$ agree with $v\left(\mathrm{C}_{\mathrm{sp}}^{3}-\mathrm{H}\right)$. The band at $1652 \mathrm{~cm}^{-1}$ for $\mathbf{1}$ is due to $v(\mathrm{COO})$. Aromatic $v(\mathrm{C}=\mathrm{C})$ stretching vibrations appear in the region 1561-1443 $\mathrm{cm}^{-1}$, and the bands in the range 12541243 and $1082-1064 \mathrm{~cm}^{-1}$ correspond to $v_{\mathrm{s}}(\mathrm{C}-\mathrm{O})_{\text {phenolic }}$ and $v$ $(\mathrm{C}-\mathrm{N})_{\text {aliphatic }}$ stretching, respectively.

The UV-Vis spectra of 1, 2, HL and $\mathrm{HL}^{\prime}$ were recorded in dichloromethane (Figs. 4, 11S, 9S and 10S). The spectra show significant transitions at $263 \mathrm{~nm}\left(\varepsilon \sim 4.647 \times 10^{3} \mathrm{~L} \mathrm{~mol}^{-1}\right)$ for $\mathbf{1}$, at $258 \mathrm{~nm}$ $\left(\varepsilon \sim 4.557 \times 10^{3} \mathrm{~L} \mathrm{~mol}^{-1}\right)$ for $\quad 2$, at $265 \mathrm{~nm} \quad\left(\varepsilon \sim 8.213 \times 10^{3}\right.$ $\left.\mathrm{L} \mathrm{mol}^{-1}\right)$ and $360 \mathrm{~nm}\left(\varepsilon \sim 3.517 \times 10^{3} \mathrm{~L} \mathrm{~mol}^{-1}\right)$ for $\mathrm{HL}$, and finally at $265 \mathrm{~nm}\left(\varepsilon \sim 8.581 \times 10^{3} \mathrm{~L} \mathrm{~mol}^{-1}\right)$ and $352 \mathrm{~nm}\left(\varepsilon \sim 3.720 \times 10^{3}\right.$ $\mathrm{L} \mathrm{mol}^{-1}$ ) for $\mathrm{HL}^{\prime}$. The bands in the region $258-265 \mathrm{~nm}$ are due to

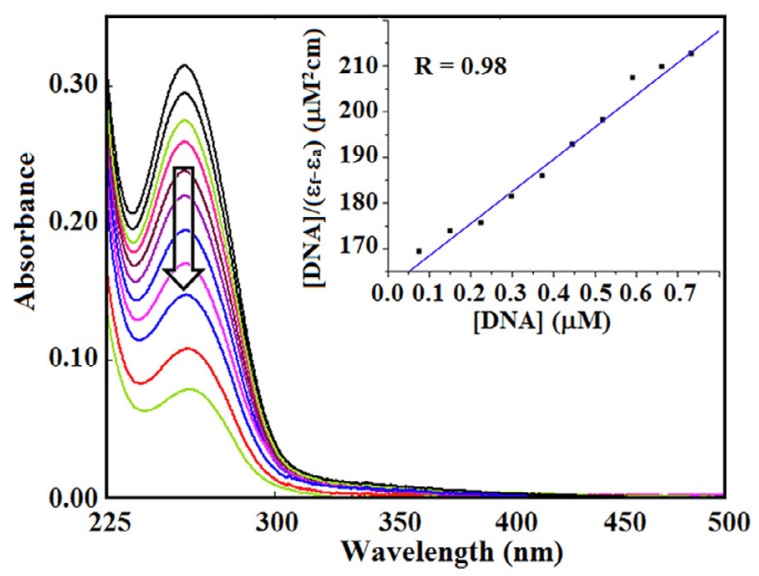

Fig. 4. Electronic absorption spectra of complex 1 ( $3 \mathrm{ml}, 0.068 \mathrm{mM}$ ) in HEPES buffer upon gradual addition of $10 \mu \mathrm{L}$ of an aqueous solution of $22.72 \mu \mathrm{M}$ CT-DNA. 
$\pi \rightarrow \pi^{*}$ of benzene ring and / or intra ligand charge transfer (ILCT) transitions and the bands in the region 352-360 nm may due to $n \rightarrow \pi^{*}$ transitions. [21b].

\subsection{ESI mass spectrometry}

The ESI mass spectrometric data (Fig. 12S) of 1 show a peak $(\mathrm{m} / \mathrm{z})$ at 922.45 , corresponding to the radical cation $[\mathrm{Cu}(\mathrm{HL})(\mathrm{pdc})]_{2}^{+}$ (for 1, calc. $m / z=925.93$ ). On the other hand, the ESI mass spectrometric data (Fig. 13S) of $\mathbf{2}^{\prime}$ shows peaks $(\mathrm{m} / \mathrm{z})$ at $681.00,558.11$, 312.00 and 249.09, corresponding to the radical cations $\left\{\left[\mathrm{Cu}\left(\mathrm{L}^{\prime}\right)_{2}\right]^{+}+3 \mathrm{CH}_{3} \mathrm{CN}\right\},\left[\mathrm{Cu}\left(\mathrm{L}^{\prime}\right)_{2}\right]^{++},\left[\mathrm{Cu}\left(\mathrm{L}^{\prime}\right)\right]^{++}$and $\left[\mathrm{HL}^{\prime}\right]^{+}$, respectively. The observed ESI mass spectral peaks indicate that in solution the metal coordination environment of complex $\mathbf{1}$ is the same as in its crystal structures, but for complex $\mathbf{2}^{\prime}$ a mononuclear species, $\left[\mathrm{Cu}\left(\mathrm{L}^{\prime}\right)_{2}\right](\mathbf{2})$, is present in solution.

\subsection{DNA binding studies}

Interactions of complexes $\mathbf{1}$ and $\mathbf{2}$ with CT-DNA were investigated using the electronic absorption spectroscopic technique. Figs. 4 and $12 \mathrm{~S}$ show the UV-Vis spectral changes of $\mathbf{1}$ and $\mathbf{2}$ upon gradual addition of $10 \mu \mathrm{L}$ of an aqueous solution of $22.72 \mu \mathrm{MCT}$ DNA. It is to be noted that the absorbances of $\mathbf{1}$ and $\mathbf{2}$ gradually decrease upon addition of CT-DNA, keeping the absorption wavelength fixed. The observed hypochromism indicates intercalative binding [22]. The hypochromicity is mainly attributed to electrostatic interactions between the compounds and the DNA bases [23].

The intrinsic binding constants $\left(K_{\mathrm{ib}}\right)$ of $\mathbf{1}$ and $\mathbf{2}$ [calculated from the [DNA] $/\left(\varepsilon_{f}-\varepsilon_{a}\right)$ versus [DNA] plot (inset of Figs. 4 and 11S)] are $5.29( \pm 0.13) \times 10^{5}, 4.18( \pm 0.21) \times 10^{5}$ and $4.35( \pm 0.14) \times 10^{5}, 2.70$ $( \pm 0.16) \times 10^{5} \mathrm{~L} \mathrm{~mol}^{-1}$, respectively.

\subsection{BSA binding studies}

The UV-Vis spectral changes (at pH 7.2) of BSA upon gradual addition of 1 and 2 are shown in Fig. 5 (a) and 16S(a). It is to be noted that the UV-Vis spectral band at $280 \mathrm{~nm}$ of BSA undergoes a hypsochromic shift ( $9 \mathrm{~nm}$ for $\mathbf{1}$ and $11 \mathrm{~nm}$ for $\mathbf{2}$ ) with an increase of the absorbance in the presence of $\mathbf{1}$ and $\mathbf{2}$. The apparent association constants $\left(K_{\mathrm{app}}\right)$ for the interaction of the compounds with BSA were calculated by using the following equation:

$\frac{1}{\left(A_{o b s}-A_{0}\right)}=\frac{1}{\left(A_{c}-A_{0}\right)}+\frac{1}{K_{a p p}\left(A_{c}-A_{0}\right)[\text { complex }]}$

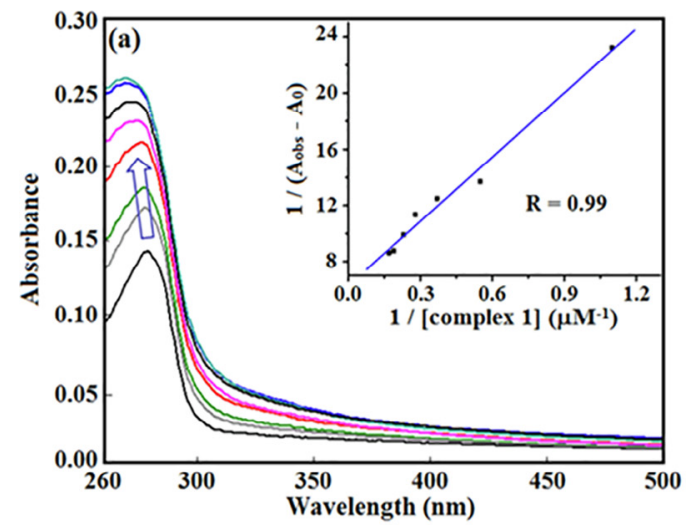

where $A_{\text {obs }}$ is the observed absorbance at $280 \mathrm{~nm}$ of the solution containing different concentrations of the complex, $A_{0}$ and $A_{c}$ are the absorbance of BSA only and of serum albumin with the complex. The calculated apparent association constants for $\mathbf{1}$ and $\mathbf{2}$ are 41.24 $( \pm 0.13) \times 10^{8}$ and $2.88( \pm 0.15) \times 10^{8} \mathrm{~L} \mathrm{~mol}^{-1}$, respectively (Table 3$)$.

We also studied BSA-compound interaction by fluorimetric analysis. Complexes $\mathbf{1}$ and $\mathbf{2}$ are non-fluorescent in dichloromethane solution. Upon excitation at $280 \mathrm{~nm}$, an aqueous solution of BSA exhibits fluorescence at $340 \mathrm{~nm}$. Figs. 5(b) and 16S(b) show quenching of the fluorescence intensity of BSA upon gradual addition of $20 \mu \mathrm{L}$ of a dichloromethane solution of $0.068 \mathrm{mM}$ complex 1. The quenching of fluorescence intensity of BSA mainly occurs due to complex formation with metal species, denaturation or conformational change of the serum albumins [24]. The Stern-Volmer constant values $\left(K_{\mathrm{sv}}\right)$ for complexes $\mathbf{1}$ and $\mathbf{2}$ interacting with BSA [25] have been calculated and the Stern-Volmer plots $I / I_{t}$ versus [complex] are shown in Figs. 20S-21S. The $K_{\text {sv }}$ values (Table 3) indicate that compounds show significant serum albumin quenching ability. The UV-Vis spectroscopic behavior of BSA upon gradual addition of the complexes reveals that the electronic absorption spectra of BSA are influenced by the addition of the complexes, thus indicating a static interaction between BSA and the compounds.

When the complex independently binds in a static mode to serum albumin in a set of equivalent sites, the equilibrium between free and bound compounds is expressed by the Scatchard equation [26]:

$\log \frac{\left(F_{0}-F\right)}{F}=\log k_{\mathrm{b}}+n \log [$ compound $]$

where $k_{\mathrm{b}}$ is the binding constant of compound with serum albumin, $n$ is the number of binding sites per serum albumin molecule. Plots of $\log \frac{\left(F_{0}-F\right)}{F}$ versus $\log$ [compound] are shown in the inset of Figs. 5(b) and $16 \mathrm{~S}(\mathrm{~b})$ for $\mathbf{1}$ and $\mathbf{2}$, respectively, and the calculated values of $k_{\mathrm{b}}$ and $n$ are given in Table 3 . It is interesting to note that complex $\mathbf{1}$ presents one binding site whereas two are observed for $\mathbf{2}$. However, 1 donates a relatively higher binding strength for BSA in comparison to 2. The values of the binding constants are high enough $\left(\sim 10^{7} \mathrm{M}^{-1}\right)$ to indicate a strong affinity of the complexes with the BSA [27] and the results are supported by the dock prediction.

\subsection{Cytotoxicity assay}

The MTT assay data reveal that complex $\mathbf{1}$ has a moderate growth suppression activity against MCF7 cells. It inhibits the growth of MCF7 cells in a dose dependent manner with an $\mathrm{IC}_{50}$

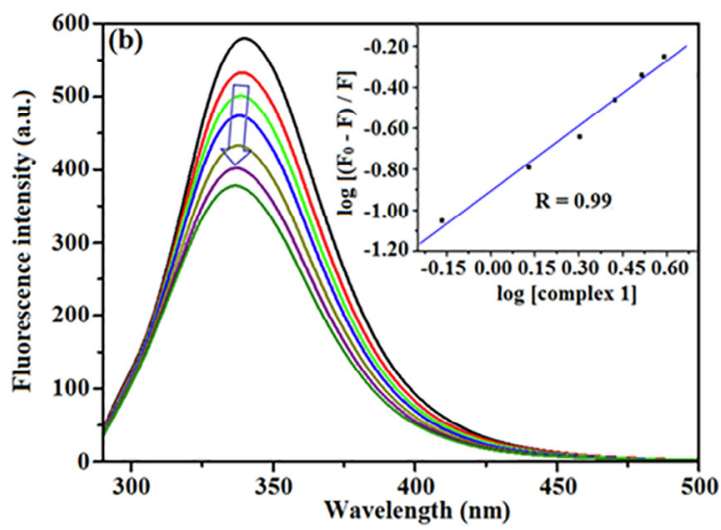

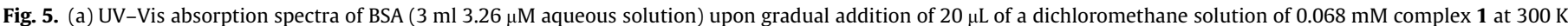

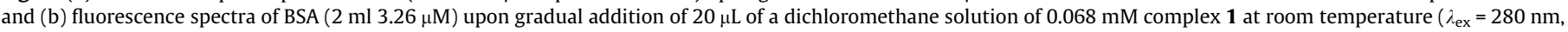
$\lambda_{\mathrm{em}}=330 \mathrm{~nm}$ ). 
Table 3

Kinetic parameters for the interaction of BSA with complexes $\mathbf{1}$ and $\mathbf{2}$.

\begin{tabular}{|c|c|c|c|c|}
\hline & $K_{\text {app }}\left(\mathrm{L} \mathrm{mol}^{-1}\right)$ & $K_{\mathrm{sv}}\left(\mathrm{L} \mathrm{mol}^{-1}\right)$ & $k_{\mathrm{b}}\left(\mathrm{L} \mathrm{mol}^{-1}\right)$ & $n$ \\
\hline $\mathrm{HL}$ & $42.29( \pm 0.17) \times 10^{8}$ & $0.21( \pm 0.11) \times 10^{8}$ & $15.12( \pm 0.16) \times 10^{8}$ & 1.34 \\
\hline $\mathrm{HL}^{\prime}$ & $13.01( \pm 0.14) \times 10^{8}$ & $0.19( \pm 0.18) \times 10^{8}$ & $12.98( \pm 0.19) \times 10^{8}$ & 1.03 \\
\hline 1 & $41.24( \pm 0.13) \times 10^{8}$ & $0.14( \pm 0.21) \times 10^{8}$ & $12.41( \pm 0.11) \times 10^{8}$ & 1.06 \\
\hline 2 & $2.88( \pm 0.15) \times 10^{8}$ & $0.12( \pm 0.23) \times 10^{8}$ & $11.70( \pm 0.17) \times 10^{8}$ & 2.59 \\
\hline
\end{tabular}

value of $24 \pm 6.24 \mu \mathrm{M}$ (Fig. 6). On the other hand, complex 2 exhibits a very mild effect on the growth of the breast cancer cell line MCF7. For example, compared to vehicle treated MCF cells, only $15 \%$ growth was inhibited in the presence of a $1 \mu \mathrm{M}$ solution of complex 2.

\subsection{Molecular docking}

\subsubsection{DNA-complex docking}

Molecular docking is a key tool to determine the mode of DNA drug interaction [28]. Figs. 7 and 21S show the minimum energy conformation for $\mathbf{1}$ and $\mathbf{2}$, respectively. The binding of $\mathbf{1}$ with DNA occurs through $\mathrm{N}-\mathrm{H}$...O hydrogen bonding interactions with A5 and A17, and intermolecular interactions with A5, A6, G16, A17, and A18, whereas 2 binds with DNA through an intermolecular interaction with $\mathrm{C} 15$ and G16. In the docked structure, both complexes interact with DNA in an intercalation mode, which is in good agreement with the UV-Vis spectrometric DNA-complex interaction study. The binding energies of docking are -342.8 and $-296.5 \mathrm{Kcal} / \mathrm{mol}$ for complexes 1 and 2, respectively, indicating a higher binding affinity for the former with respect to complex 2.

\subsubsection{BSA-complex docking}

In order to corroborate our experimental results, the molecular docking technique has been used to recognize the complex protein interactions. The Chimera scores of the individual complexes with different poses have been tabulated in Table 3S. Since BSA has two different active sites for binding (Tyr 149 and Tyr 410), we performed docking of each complex with each of these binding sites in order to investigate the effective interaction of BSA with our complexes. Based on the Chimera score (Table 3S), both complexes selectively bind with BSA at site Tyr 149. The interactions between the complexes and RCSB protein are shown in Figs. 8-9 and 22S, 23S.

The results of the docking study indicate the formation of $\mathrm{N}-\mathrm{H} \cdots \mathrm{O}$ and $\mathrm{N}-\mathrm{H} \cdots \mathrm{N}$ bonds between the complexes and the pro-

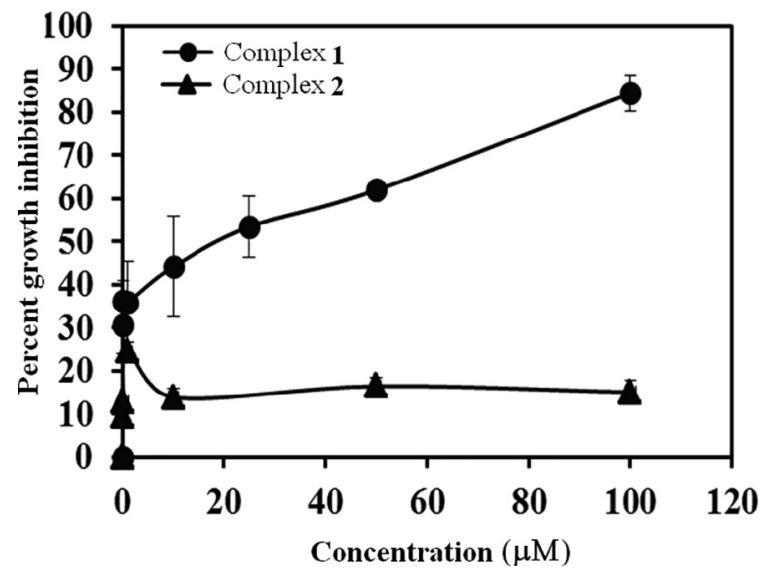

Fig. 6. Dose dependent suppression of cell viability of human breast cancer cell line MCF7 by complexes $\mathbf{1}$ and $\mathbf{2}$.

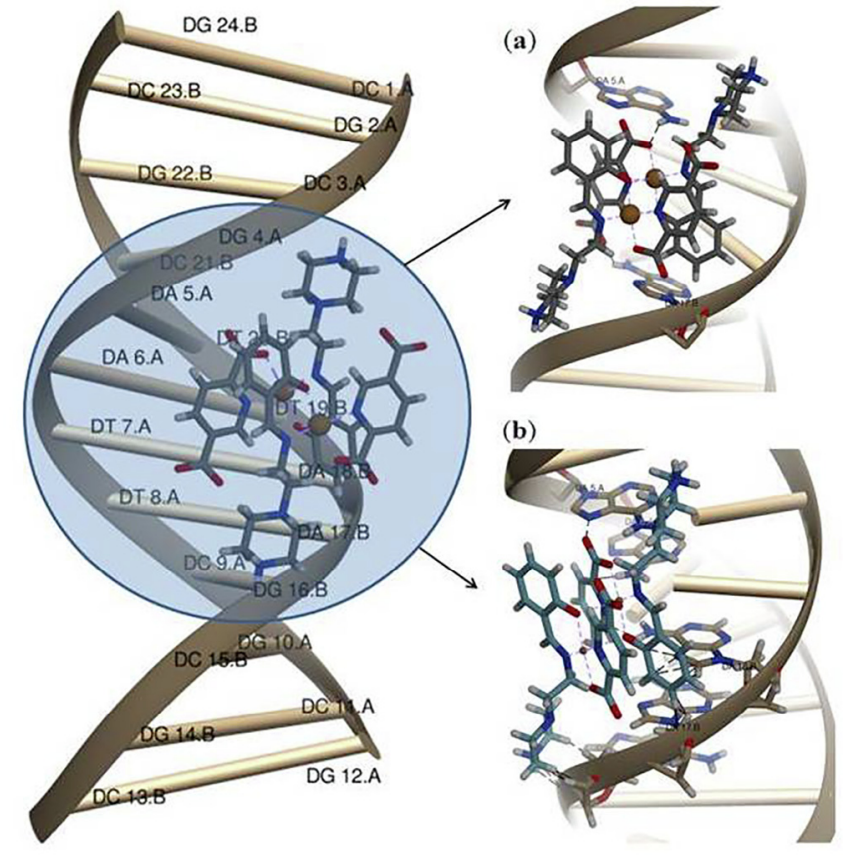

Fig. 7. Molecular docking of $\mathbf{1}$ with B-DNA, showing the binding sites, (a) hydrogen bonding and (b) intermolecular interactions.

tein, as presented in Table 4. Thus, both complexes form two hydrogen bonds with BSA when they bind at the Tyr149 site. On the other hand, at the Tyr410 site, only complex 2 exhibits one hydrogen bond with BSA. In addition to H-bonding interactions, we also analyzed hydrophobic and van der Waal's interactions (Table 4S). The analysis indicates that 1 undergoes hydrophobic interactions with Leu237, Val240 (active site Tyr149) and Leu386, Asn390, Phe402, Leu406, Leu429, Leu452, Leu456, Phe487 (active site Tyr410), and 2 undergoes hydrophobic interactions with Phe148, Leu237, Val240, Ala256, Ala290 (active site Tyr149) and Leu386, Leu429, Leu452, Leu490, Pro492 (active site Tyr410). The polar amino acids interacting with complexes are: Tyr149, Tyr156, Ser191, Trp213, His241, Cys244, His287 (active site Tyr149) and Tyr410, Ser488 (active site Tyr410) for 2 and Tyr149, Tyr156, Ser191, Gln195, His287 (active site Tyr149) and Asn390, Tyr410, Ser488 (active site Tyr410) for 1.

\section{Conclusion}

In summary, we have presented here the synthesis, crystal structure, DNA/protein binding, cytotoxicity studies and molecular docking of two copper(II) complexes. Crystal structure analysis reveals that in the solid state both $[\mathrm{Cu}(\mathrm{HL})(\mathrm{pdc})]_{2}(\mathbf{1})$ and $[\mathrm{Cu}$ $\left.\left(\mathrm{L}^{\prime}\right)_{2}\right]_{2}\left(\mathbf{2}^{\prime}\right)$ are dinuclear, and in both the complexes the Schiff base acts as a bidentate ligand. These complexes manifest a tendency to form dimers so as to modify the coordination geometry from square planar to square pyramidal. The ESI mass spectrometric analysis reveals that in solution complex $\mathbf{1}$ retains its dinuclear 


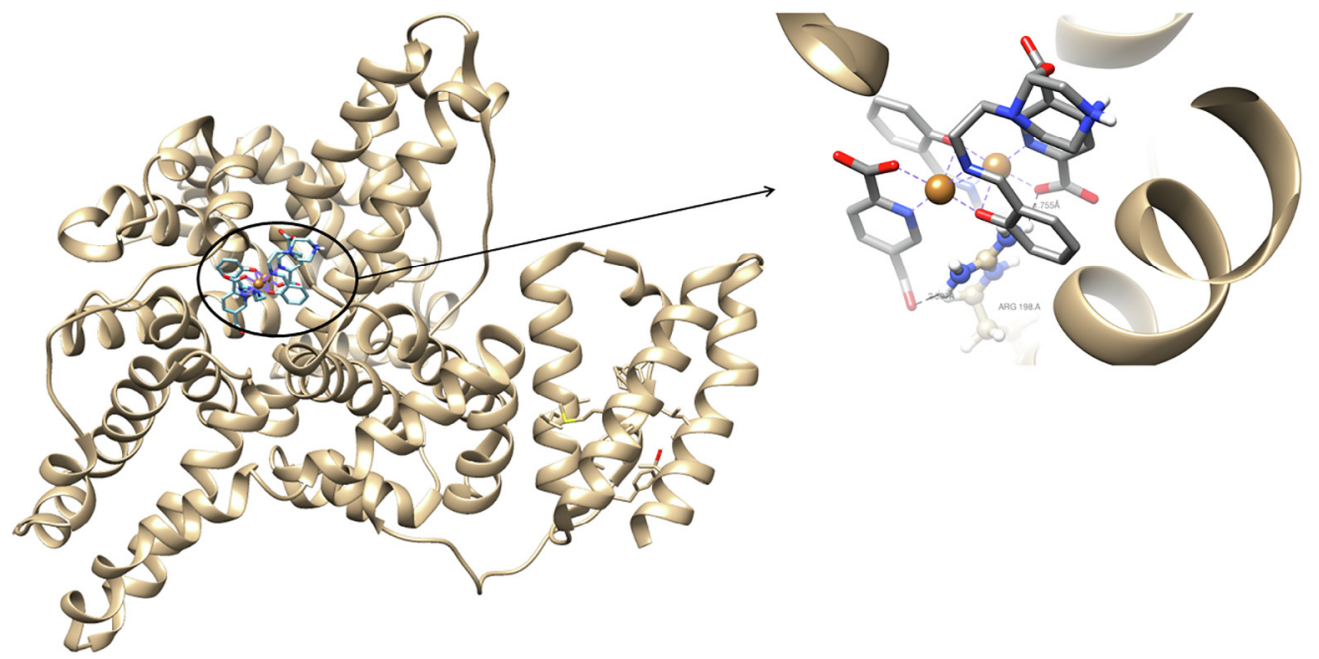

Fig. 8. Molecular docking of 1 with BSA (binding site: Tyr149) showing the binding sites and hydrogen bonding interactions.

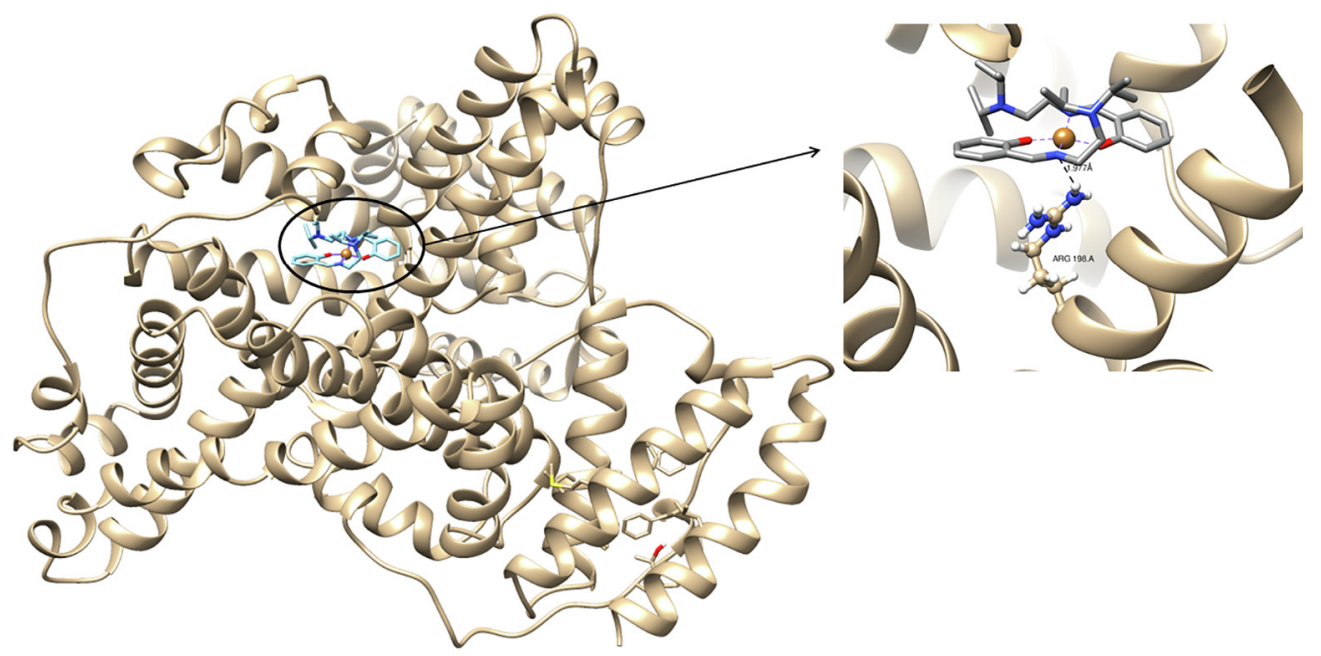

Fig. 9. Molecular docking of 2 with BSA (binding site: Tyr149) showing the binding sites and hydrogen bonding interactions.

Table 4

Hydrogen bonding interactions of complexes $\mathbf{1}$ and $\mathbf{2}$ with B-DNA and BSA.

\begin{tabular}{llll}
\hline Complex & Bonds formed & $\mathrm{D} \cdots \mathrm{A}(\AA)$ & $\mathrm{D}-\mathrm{H} \cdots \mathrm{A}(\AA)$ \\
\hline B-DNA & & & \\
$\mathbf{1}$ & $\mathrm{N}-\mathrm{H}(\mathrm{A} 5) \cdots \mathrm{O}$ & 2.927 & 2.010 \\
& $\mathrm{~N}-\mathrm{H}(\mathrm{A} 17) \cdots \mathrm{O}$ & 3.226 & 2.396 \\
& & & \\
BSA & & & \\
$\mathbf{1}$ (Active site: Tyr149) & $\mathrm{N}-\mathrm{H}(\operatorname{Arg} 198) \cdots \mathrm{O}$ & 3.202 & 2.307 \\
& $\mathrm{~N}-\mathrm{H}(\operatorname{Arg} 198) \cdots \mathrm{O}$ & 2.612 & 1.755 \\
$\mathbf{2}$ (Active site: Tyr149) & $\mathrm{N}-\mathrm{H}(\operatorname{Arg} 198) \cdots \mathrm{N}$ & 2.812 & 1.977 \\
$\mathbf{2}$ (Active site: Tyr410) & $\mathrm{N}-\mathrm{H}(\operatorname{Arg} 409) \cdots \mathrm{N}$ & 3.599 & 2.700 \\
\hline
\end{tabular}

composition, whereas, complex $\mathbf{2}^{\prime}$, exists as mononuclear $\left[\mathrm{Cu}\left(\mathrm{L}^{\prime}\right)_{2}\right]$ (2). Spectroscopic and molecular docking studies indicate that both complexes $\mathbf{1}$ and $\mathbf{2}$ interact with serum albumin, binding BSA at the Tyr149 site. In addition, both 1 and $\mathbf{2}$ interact with CT-DNA via the intercalation binding mode. The MTT assay results indicate that complex 1 shows higher anticancer activity on the human breast cancer cell line MCF7.

\section{Acknowledgements}

The authors gratefully acknowledge the financial assistance given by the CSIR, Government of India, to Dr. Subal Chandra
Manna (Project No. 01 (2743)/13/EMR-II). Dr. S. C. Manna thanks UGC-SAP and DST-FIST New Delhi and Vidyasagar University for infrastructural facilities.

\section{Appendix A. Supplementary data}

CCDC 1839877 and 1019784 contains the supplementary crystallographic data for $\mathbf{1}$ and $\mathbf{2}^{\prime}$. These data can be obtained free of charge via http://www.ccdc.cam.ac.uk/conts/retrieving.html, or from the Cambridge Crystallographic Data Centre, 12 Union Road, Cambridge CB2 1EZ, UK; fax: (+44) 1223-336-033; or e-mail: deposit@ccdc.cam.ac.uk. Supplementary data to this article can be found online at https://doi.org/10.1016/j.poly.2019.06.049.

\section{References}

[1] (a) S. Shleev, J. Tkac, A. Christenson, T. Ruzgas, A.I. Yaropolov, J.W. Whittaker, L. Gorton, Biosens. Bioelectron. 20 (2005) 2517;

(b) S. Hattori, Y. Wada, S. Yanagida, S. Fukuzumi, J. Am. Chem. Soc. 127 (2005) 9648;

(c) K.A. Magnus, H. Ton-That, J.E. Carpenter, Chem. Rev. 94 (1994) 727.

[2] R. Cowley, J.R. Dilworth, P.S. Donnelly, J.M. White, Inorg. Chem. 45 (2006) 496

[3] (a) M. Theetharappan, L. Subha, C. Balakrishnan, M.A. Neelakantan, Appl. Organometal Chem. (2017) e3713;

(b) S.S. Bhat, A.A. Kumbhar, H. Heptullah, A.A. Khan, V.V. Gobre, S.P. Gejji, V.G. 
Puranik, Inorg. Chem. 50 (2011) 545;

(c) P. Jaividhya, M. Ganeshpandian, R. Dhivya, M.A. Akbarsha, M. Palaniandavar, Dalton Trans. 44 (2015) (2010) 11997.

[4] (a) F.-H. He, L. Tao, X.-W. Li, Y.-T. Li, Z.-Y. Wu, C.-W. Yan, New J. Chem. 36 (2012) 2078;

(b) A. Paul, S. Mistri, A. Bhunia, S. Manna, H. Puschmann, S.C. Manna, RSC Adv. 6 (2016) 60487;

(c) A. Paul, A. Figuerola, V. Bertolasi, S.C. Manna, Polyhedron 119 (2016) 460;

(d) K. Das, S. Dolai, P. Vojtíšj ek, S.C. Manna, Polyhedron 149 (2018) 7-16;

(e) S. Mistri, A. Patra, M. Santra, D. Paul, E. Zangrando, H. Puschmann, S.C. Manna, Chemistry Select 3 (2018) 9102-9112;

(f) A. Paul, H. Puschmann, S.C. Manna, Polyhedron 155 (2018) 447-456;

(g) S. Manna, E. Zangrando, H. Puschmann, S.C. Manna, Polyhedron 162 (2019) 285-292;

(h) S. Dolai, K. Das, V. Bertolasi, S.C. Manna, Appl Organometal Chem. (2018) e4506;

(i) A. Bhunia, S. Mistri, R.K. Manne, M.K. Santra, S.C. Manna, Inorg. Chim. Acta 491 (2019) 25-33;

(j) A. Bhunia, P. Vojtísek, S.C. Manna, J. Mol. Struct. 1179 (2019) 558-567.

[5] (a) P.P. Netalkar, S.P. Netalkar, V.K. Revankar, Appl. Organometal. Chem. 29 (2015) 280;

(b) B.J. Pages, D.L. Ang, E.P. Wright, J.R. Aldrich-Wright, Dalton Trans. 44 (2015) 3505.

[6] (a) C. Deegan, B. Coyle, M. McCann, M. Devereux, D.A. Egan, Chem. Biol Interact. 164 (2006) 115;

(b) S. Dhar, A.R. Chakravarty, Inorg. Chem. 42 (2003) 2483;

(c) B.K. Santra, P.A.N. Reddy, G. Neelakanta, S. Mahadevan, M. Nethaji, A.R. Chakravarty, J. Inorg. Biochem. 89 (2002) 191;

(d) A.M. Thomas, M. Nethaji, S. Mahadevan, A.R. Chakravarty, J. Inorg. Biochem. 94 (2003) 171;

(e) Á. Garcła-Raso, J.J. Fiol, B. Adrover, V. Moreno, I. Mata, E. Espinosa, E. Molins, J. Inorg. Biochem. 95 (2003) 77;

(f) L.-P. Lu, M.-L. Zhu, P. Yang, J. Inorg. Biochem. 95 (2003) 31.

[7] (a) M.B. Kristensen, Clin. Pharmacokinet. 1 (1976) 351;

(b) M. Sousa, A. Pozniak, M. Boffito, J. Antimicrob. Chemother. 62 (2008) 872.

[8] D.D. Perrin, W.L.F. Armarego, D.R. Perrin, Purification of Laboratory Chemicals, Pergamon Press, Oxford, U.K., 1980.

[9] Agilent, CrysAlisPRO, Agilent Technologies UK Ltd, Yarnton, England, 2012.

[10] Bruker, APEX2, SAINT, Bruker AXS Inc., Madison, Wisconsin, USA, 2007.

[11] L. Palatinus, G. Chapuis, J. Appl. Cryst. 40 (2007) 786.
[12] G.M. Sheldrick, Acta Cryst., A 64 (2008) 112.

[13] O.V. Dolomanov, L.J. Bourhis, R.J. Gildea, J.A.K. Howard, H. Puschmann, J. Appl. Cryst. 42 (2009) 229.

[14] L.J. Farrugia, J. Appl. Cryst. 45 (2012) 849.

[15] A. Wolfe, G.H. Shimer, T. Mechan, Biochemistry 26 (1987) 6392.

[16] (a) S.U. Rehman, Z. Yaseen, M.A. Husain, T. Sarwar, H.M. Ishqi, M. Tabish, PLOS ONE 9 (2014) e93913; (b) Gaussian 09, rev. A.02, (Gaussian Inc, Wallingford, CT) 2009

[17] Y.-X. Si, Z.-J. Wang, D. Park, H.Y. Chung, S.-F. Wang, L. Yan, J.-M. Yang, G.-Y. Qian, S.-J. Yin, Y.-D. Park, Int. J. Bio. Macro. 50 (2012) 257.

[18] (a) M. Pait, B. Kundu, S.C. Kundu, D. Ray, Inorg. Chim. Acta 417 (2014) 30; (b) O.V. Nesterova, D.S. Nesterov, A. Krogul, M.F.C. Guedes da Silva, A.J.L. Pombeiro, J. Mol. Catal. A: Chem. 426 (2017) 506.

[19] R. Kumar, K. Mahiya, P. Mathur, Dalton Trans. 42 (2013) 8553.

[20] (a) S. Basak, S. Sen, P. Roy, C.J. Gómez-García, D.L. Hughes, R.J. Butcher, E. Garribba, S. Mitra, Aust. J. Chem. 63 (2009) 479;

(b) A. Biswas, M.G.B. Drew, Y. Song, A. Ghosh, Inorg. Chim. Acta 376 (2011) 422.

[21] (a) K. Nakamoto, Infrared Spectra of Inorganic and Coordination Compounds, John Wiley \& Sons, New York, 1997;

(b) N. Raman, S. Ravichandran, C. Thangaraja, J. Chem. Sci. 116 (2004) 215.

[22] J.K. Barton, J.J. Dennenberg, J.B. Chaires, Biochemistry 32 (1993) 2573.

[23] B.D. Wang, Z.Y. Yang, P. Crewdson, D.Q. Wang, J. Inorg. Biochem. 101 (2007) 1492.

[24] (a) Z. Liu, X. Zheng, X. Yang, E. Wang, J. Wang, Biophysical 96 (2009) 3917;

(b) A.B.T. Ghisaidoobe, S.J. Chung, Int. J. Mol. Sci. 15 (2014) 22518;

(c) Y. Wang, G. Zhang, Luminescence 30 (2015) 198.

[25] J.R. Lakowicz, Principles of Fluorescence Spectroscopy, third ed., Springer, New York, USA, 2006

[26] (a) J.R. Lakowicz, Fluorescence Quenching: Theory and applications, Principles of Fluorescence Spectroscopy, Kluwer Academic/Plenum Publishers, New York, 1999, p. 53;

(b) X.-Z. Feng, Z. Lin, L.-J. Yang, C. Wang, C.-L. Bai, Talanta 47 (1998) 1223.

[27] M. Zampakou, N. Rizeq, V. Tangoulis, A.N. Papadopoulos, F. Perdih, I. Turel, G. Psomas, Inorg. Chem. 53 (2014) 2040.

[28] (a) N. Shahabadi, S.M. Fili, F. Kheirdoosh, J. Photochem. Photobiol., B 128 (2013) 20;

(b) F. Caruso, M. Rossi, A. Benson, C. Opazo, D. Freedman, J. Med. Chem. 55 (2012) 1072 